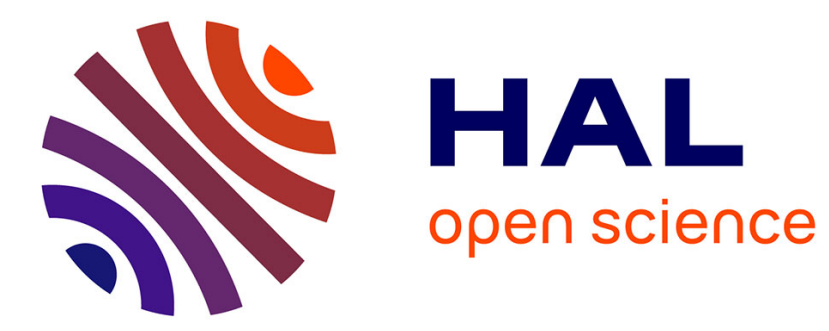

\title{
Diastereoselective Synthesis of N-tert-Butanesulfinylamines through Addition of p-Nitrobenzyl Chloride to N-tert-Butanesulfinimines Using a TDAE Strategy
}

Cédric Spitz, Omar Khoumeri, Thierry Terme, Patrice Vanelle

\section{To cite this version:}

Cédric Spitz, Omar Khoumeri, Thierry Terme, Patrice Vanelle. Diastereoselective Synthesis of N-tertButanesulfinylamines through Addition of p-Nitrobenzyl Chloride to N-tert-Butanesulfinimines Using a TDAE Strategy. SYNLETT, 2013, 10.1055/s-0033-1339178 . hal-01425566

\section{HAL Id: hal-01425566 \\ https://hal-amu.archives-ouvertes.fr/hal-01425566}

Submitted on 3 Jan 2017

HAL is a multi-disciplinary open access archive for the deposit and dissemination of scientific research documents, whether they are published or not. The documents may come from teaching and research institutions in France or abroad, or from public or private research centers.
L'archive ouverte pluridisciplinaire HAL, est destinée au dépôt et à la diffusion de documents scientifiques de niveau recherche, publiés ou non, émanant des établissements d'enseignement et de recherche français ou étrangers, des laboratoires publics ou privés. 


\title{
Diastereoselective Synthesis of $N$-tert-Butanesulfinylamines through Addition of $p$-Nitrobenzyl Chloride to $N$-tert-Butanesulfinimines Using a TDAE Strategy
}

\author{
Cédric Spitz, Omar Khoumeri, Thierry Terme, Patrice Vanelle* \\ Aix-Marseille Université, Institut de Chimie Radicalaire ICR, UMR CNRS 7273, Laboratoire de Pharmaco-Chimie Radicalaire, Faculté de \\ Pharmacie, 27 Boulevard Jean Moulin - CS 30064, 13385 Marseille Cedex 05, France \\ Fax +33(4)91794677; E-mail: patrice.vanelle@univ-amu.fr \\ Received: 28.03.2013; Accepted after revision: 10.05.2013
}

\begin{abstract}
An easy and efficient method of diastereoselective synthesis of $N$-tert-butanesulfinylamines using a TDAE strategy was developed. Good yields and diastereoselectivities were achieved using readily available $N$-tert-butanesulfinimines and commercially available $p$-nitrobenzyl chloride.
\end{abstract}

Key words: $N$-tert-butanesulfinimines, TDAE, addition, chiral auxiliary

diastereoselectivity,

The asymmetric synthesis of amines has received much attention in recent years due to the fact that the amine functionality is present in many biologically active compounds. ${ }^{1}$ Adding organometallic reagents to $N$-sulfinimines is one of the most commonly used methods for the asymmetric synthesis of amines. ${ }^{2}$ When a nucleophile is added to enantiomerically pure $N$-tert-butanesulfinimines, it usually leads to amines in good yields and diastereoselectivities. Furthermore, the tert-butanesulfinyl chiral auxiliary can be removed easily under acidic conditions, giving the corresponding chiral primary amines. However, a disadvantage of the use of organometallic reagents such as Grignard or organolithium reagents is the poor functional-group tolerance. Recently, Ellman and co-workers reported the $\mathrm{MgCl}_{2}$-enhanced addition of benzyl zinc reagents to $N$-tert-butanesulfinimines with good yields, diastereoselectivities, and better functionalgroup tolerance. ${ }^{3}$

Tetrakis(dimethylamino)ethylene (TDAE) is an organic reducing agent, which reacts with halogenated derivatives to generate a carbanion under mild conditions. ${ }^{4}$ Since 2003, we have undertaken a program directed toward the development of original synthetic methods using TDAE methodology in medicinal chemistry. ${ }^{5}$ In particular, we have shown that from $o$ - and $p$-nitrobenzyl chlorides, TDAE was able to generate a nitrobenzyl carbanion, which can react with various electrophiles such as aromatic aldehydes, $\alpha$-ketoester, ketomalonate, $\alpha$-ketolactam, and sulfonimine derivatives. ${ }^{6}$

To the best of our knowledge, the addition of organometallic reagents bearing a nitro group to $N$-tert-butanesulfinimines has never been described, probably due to

SYNLETT, 2013, 1725-1727

Advanced online publication: 20.06.2013

DOI: 10.1055/s-0033-1339178; Art ID: ST-2013-D0279-L

(C) Georg Thieme Verlag Stuttgart · New York the difficulty of generating organometallic nitro compounds. ${ }^{7}$ As part of our research program, ${ }^{8}$ we report herein the application of our TDAE methodology for the diastereoselective addition of $p$-nitrobenzyl chloride to a variety of enantiopure $(R)-N$-tert-butanesulfinimines to produce chiral amines in good yields and diastereoselectivities.

The reaction between $p$-nitrobenzyl chloride (1) and various enantiopure aromatic $N$-sulfinimines $\mathbf{2 a}-\mathbf{j}$ in the presence of TDAE at $-20^{\circ} \mathrm{C}$ for one hour, followed by two

Table 1 Diastereoselective Addition of $p$-Nitrobenzyl Chloride (1) to Aromatic Sulfinimines 2a-j Using TDAE Strategy ${ }^{\mathbf{a}}$

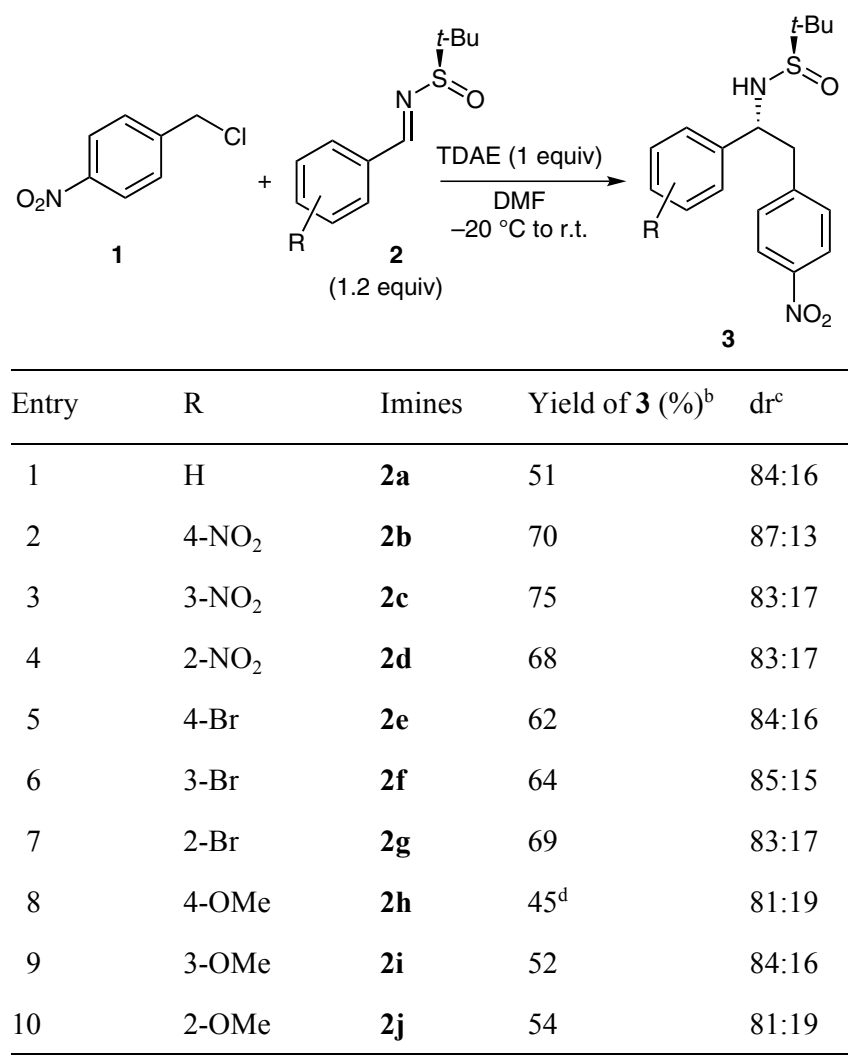

${ }^{a}$ Reactions were performed using 1 equiv of chloride $1,1.2$ equiv of imines $2 \mathbf{a}-\mathbf{j}$, and 1 equiv of TDAE in anhyd DMF stirred at $-20^{\circ} \mathrm{C}$ for $1 \mathrm{~h}$ and then maintained at r.t. for $2 \mathrm{~h}$.

${ }^{\mathrm{b}}$ Isolated yield of a mixture of diastereoisomers after purification by chromatography.

${ }^{\mathrm{c}}$ Determined by ${ }^{1} \mathrm{H}$ NMR analysis of the crude mixture.

${ }^{\mathrm{d}}$ Conditions: 1 equiv of imine $\mathbf{2 h}, 3$ equiv of chloride $\mathbf{1}$, and 3 equiv of TDAE were used. 


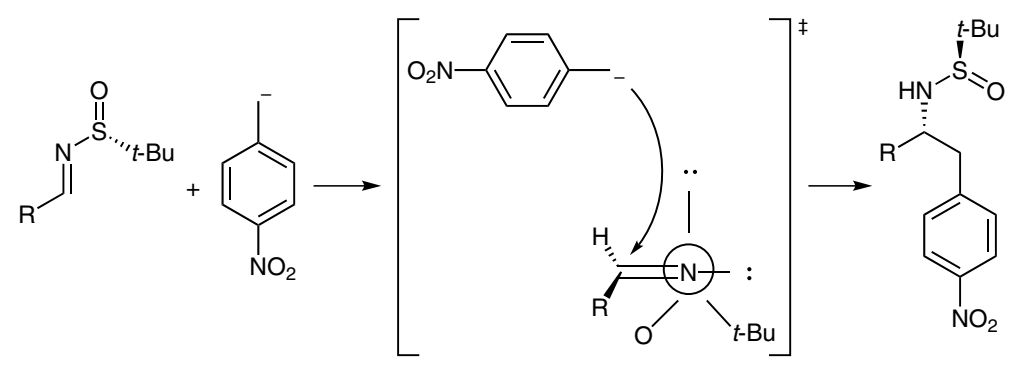

Scheme 1 Stereochemical induction

hours at room temperature led to the corresponding amines $^{9}$ in good yields (45-75\%) and diastereoselectivities (from 81:19 to 87:13) as shown in Table 1. Reactions with both electron-poor (entries 2-7) and electron-rich (entries 8-10) aromatic imines produced good yields and good diastereoselectivities. As expected, electron-rich aromatic imines resulted in a slightly diminished yield. Para, meta, and ortho substitution were all well tolerated and, encouragingly, did not affect the diastereoselectivity.

The absolute configuration of the major diastereoisomer of amine $\mathbf{3 b}$ was assigned as $R, R$ by $\mathrm{X}$-ray structural analysis (Figure 1). ${ }^{10}$

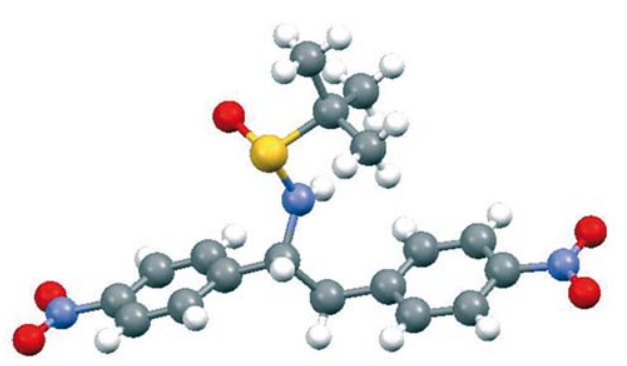

Figure 1 X-ray crystal structure of major diastereoisomer $(R, R)-\mathbf{3 b}$

The direction of induction is consistent with an open transition state as proposed for a number of $N$-tert-butanesulfinimines addition reactions (Scheme 1).,

Besides the mild reaction conditions and the simplicity of the purification procedure, another advantage associated with this method is that it produces $N$-tert-butanesulfinylprotected amines. Such a protecting group is easy to cleave under acidic conditions. ${ }^{11}$ For example, when amine $(R, R)-3 \mathbf{b}$ was subjected to $\mathrm{HCl}$ in dioxane$\mathrm{MeOH},{ }^{12}$ primary amine $(R)-\mathbf{4 b}$ was obtained in $75 \%$ yield (Scheme 2).

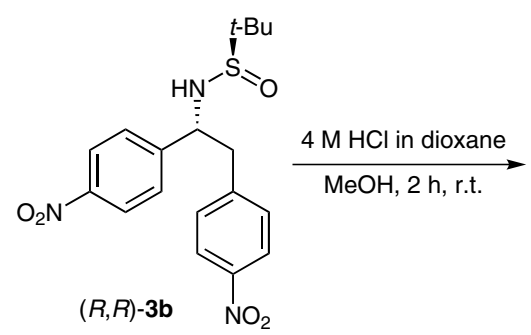<smiles>N[C@@H](Cc1ccc([N+](=O)[O-])cc1)c1ccc([N+](=O)[O-])cc1</smiles>

(R)-4b $75 \%$

In conclusion, the diastereoselective addition of $p$-nitrobenzyl chloride to $N$-tert-butanesulfinimines using the TDAE strategy allowed the synthesis of $N$-tert-butanesulfinylamines in good yields and diastereoselectivities. Furthermore, the primary amines can be obtained easily by deprotection of the sulfinyl group under acidic conditions. The tolerance of nitro groups suggests this method is a good alternative to the use of organometallic reagents to prepare enantiopure primary amines containing nitro substituents. Further research is in progress to extend the scope to other type of $N$-tert-butanesulfinimines.

\section{Acknowledgment}

This work was supported by the CNRS and the Aix-Marseille University. The authors thank the Spectropole team for elemental analysis. We express our thanks to V. Remusat for ${ }^{1} \mathrm{H} \mathrm{NMR}$ and ${ }^{13} \mathrm{C}$ NMR spectra recording and to T. Schembri and D. Lafitte (Marseille Protéomique - PIT2) for HRMS spectra recording.

Supporting Information for this article is available online at http://www.thieme-connect.com/ejournals/toc/synlett.

\section{References and Notes}

(1) Hili, R.; Yudin, A. K. Nat. Chem. Biol. 2006, 2, 284.

(2) Robak, M. T.; Herbage, M. A.; Ellman, J. A. Chem. Rev. 2010, 110, 3600 .

(3) Buesking, A. W.; Baguley, T. D.; Ellman, J. A. Org. Lett. 2011, 13, 964.

(4) (a) Takechi, N.; Aït-Mohand, S.; Médebielle, M.; Dolbier, W. R. Jr. Tetrahedron Lett. 2002, 43, 4317. (b) Pooput, C.; Médebielle, M.; Dolbier, W. R. Jr. Org. Lett. 2004, 6, 301. (c) Pooput, C.; Médebielle, M.; Dolbier, W. R. Jr. J. Org. Chem. 2006, 71, 3564.

(5) (a) Montana, M.; Terme, T.; Vanelle, P. Tetrahedron Lett. 2006, 47, 6573. (b) Montana, M.; Crozet, M. D.; CasteraDucros, C.; Terme, T.; Vanelle, P. Heterocycles 2008, 75 , 925. (c) Since, M.; Terme, T.; Vanelle, P. Tetrahedron 2009, 65, 6128. (d) Juspin, T.; Terme, T.; Vanelle, P. Synlett 2009, 1485. (e) Nadji-Boukrouche, A. R.; Khoumeri, O.; Terme, T.; Liacha, M.; Vanelle, P. ARKIVOC 2010, (x), 358. (f) Montana, M.; Terme, T.; Vanelle, P. Lett. Org. Chem. 2010, 7, 453. (g) Juspin, T.; Giuglio-Tonolo, G.; Terme, T.; Vanelle, P. Synthesis 2010, 844.

(6) (a) Giuglio-Tonolo, G.; Terme, T.; Médebielle, M.; Vanelle, P. Tetrahedron Lett. 2003, 44, 6433. (b) Giuglio-Tonolo, G.; Terme, T.; Médebielle, M.; Vanelle, P. Tetrahedron Lett. 2004, 45, 5121. (c) Khoumeri, O.; Terme, T.; Vanelle, P. Synthesis 2009, 3677. (d) Khoumeri, O.; Giuglio-Tonolo, G.; Crozet, M. D.; Terme, T. M.; Vanelle, P. Tetrahedron 
2011, 67, 6173. (e) Khoumeri, O.; Terme, T.; Vanelle, P. Tetrahedron Lett. 2012, 53, 2410.

(7) Sapountzis, I.; Dube, H.; Lewis, R.; Gommermann, N.; Knochel, P. J. Org. Chem. 2005, 70, 2445.

(8) (a) Vanelle, P.; De Meo, M. P.; Maldonado, J.; Nouguier, R.; Crozet, M. P.; Laget, M.; Dumenil, G. Eur. J. Med. Chem. 1990, 241. (b) El-Kashef, H. S.; El-Emary, T. I.; Gasquet, M.; Timon-David, P.; Maldonado, J.; Vanelle, P. Pharmazie 2000, 55, 572. (c) Boufatah, N.; Gellis, A.; Maldonado, J.; Vanelle, P. Tetrahedron 2004, 60, 9131. (d) Gellis, A.; Kovacic, H.; Boufatah, N.; Vanelle, P. Eur. J. Med. Chem. 2008, 858 .

(9) General Procedure

To a stirred solution of $N$-sulfinimine $2(0.24 \mathrm{mmol})$ in DMF $(1 \mathrm{~mL})$ at $-20^{\circ} \mathrm{C}$ was added TDAE $(0.2 \mathrm{mmol})$ followed by dropwise addition of a solution of $p$-nitrobenzyl chloride (1) in DMF $(1 \mathrm{~mL})$. The solution was vigorously stirred at $20{ }^{\circ} \mathrm{C}$ for $1 \mathrm{~h}$ and then maintained at r.t. for $2 \mathrm{~h} . \mathrm{H}_{2} \mathrm{O}(5 \mathrm{~mL})$ was added, and the aqueous solution was extracted with $\mathrm{CH}_{2} \mathrm{Cl}_{2}(3 \times 15 \mathrm{~mL})$. The combined organic layer was washed with $\mathrm{H}_{2} \mathrm{O}(20 \mathrm{~mL})$ and dried over $\mathrm{MgSO}_{4}$. Filtration and evaporation of the solvent furnished the crude product. Purification by silica gel chromatography (EtOAc-PE: from $6: 4$ to $8: 2$ depending on the polarity of substrates) allowed pure amine products 3 as a mixture of diastereoisomers. $N$-[1,2-Bis(4-nitrophenyl)ethyl]-2-methylpropane-2sulfinamide (3b)

Major Diastereoisomer $(R, R)$

Yellow solid; mp $171-174{ }^{\circ} \mathrm{C} .{ }^{1} \mathrm{H}$ NMR $\left(200 \mathrm{MHz}, \mathrm{CDCl}_{3}\right)$ : $\delta=8.16(\mathrm{~d}, J=8.6 \mathrm{~Hz}, 2 \mathrm{H}), 8.08(\mathrm{~d}, J=8.5 \mathrm{~Hz}, 2 \mathrm{H}), 7.40$ $(\mathrm{d}, J=8.6 \mathrm{~Hz}, 2 \mathrm{H}), 7.18(\mathrm{~d}, J=8.5 \mathrm{~Hz}, 2 \mathrm{H}), 4.80-4.70(\mathrm{~m}$, $1 \mathrm{H}), 3.67$ (d, $J=4.7 \mathrm{~Hz}, 1 \mathrm{H}), 3.48$ (dd, $J=13.5,6.2 \mathrm{~Hz}, 1$ $\mathrm{H}), 3.13(\mathrm{dd}, J=13.5,7.7 \mathrm{~Hz}, 1 \mathrm{H}), 1.17(\mathrm{~s}, 9 \mathrm{H}) \cdot{ }^{13} \mathrm{C} \mathrm{NMR}$ $\left(50 \mathrm{MHz}, \mathrm{CDCl}_{3}\right): \delta=48.2,147.8,147.1,144.3,130.5$, $128.3,124.2,123.8,60.1,56.6,43.0,22.6$. ESI-HRMS: $\mathrm{m} / \mathrm{z}$ $[\mathrm{M}+\mathrm{Na}]^{+}$calcd for $\left[\mathrm{C}_{18} \mathrm{H}_{21} \mathrm{~N}_{3} \mathrm{O}_{5} \mathrm{SNa}\right]^{+}: 414.10941$; found: 414.10979.

\section{Minor Diastereoisomer $(R, S)$}

Yellow solid; mp $145-148{ }^{\circ} \mathrm{C}$. ${ }^{1} \mathrm{H}$ NMR $\left(200 \mathrm{MHz}, \mathrm{CDCl}_{3}\right)$ : $\delta=8.18(\mathrm{~d}, J=8.8 \mathrm{~Hz}, 2 \mathrm{H}), 8.12(\mathrm{~d}, J=8.7 \mathrm{~Hz}, 2 \mathrm{H}), 7.39$ $(\mathrm{d}, J=8.8 \mathrm{~Hz}, 2 \mathrm{H}), 7.19(\mathrm{~d}, J=8.7 \mathrm{~Hz}, 2 \mathrm{H}), 4.86-4.79(\mathrm{~m}$, $1 \mathrm{H}$ ), 3.58 (br s, $1 \mathrm{H}), 3.24$ (dd, $J=7.3,3.6 \mathrm{~Hz}, 2 \mathrm{H}), 1.19$ (s, $9 \mathrm{H}) .{ }^{13} \mathrm{C}$ NMR $\left(50 \mathrm{MHz}, \mathrm{CDCl}_{3}\right): \delta=148.0,147.7,147.4$, 143.3, 130.5, 128.7, 124.11, 124.08, 59.0, 56.3, 44.7, 22.6. ESI-HRMS: $m / z[\mathrm{M}+\mathrm{Na}]^{+}$calcd for $\left[\mathrm{C}_{18} \mathrm{H}_{21} \mathrm{~N}_{3} \mathrm{O}_{5} \mathrm{SNa}\right]^{+}$: 414.10941; found: 414.10982.

(10) CCDC 929478 contains the supplementary crystallographic data of compound $(R, R)-\mathbf{3 b}$ for this paper. These data can be obtained free of charge from The Cambridge Crystallographic Data Centre via http://www.ccdc.cam.ac.uk/data_request/cif.

(11) Cogan, D. A.; Ellman, J. A. J. Am. Chem. Soc. 1999, 121, 268.

(12) Deprotection of Amine $(\boldsymbol{R}, \boldsymbol{R})-3 \mathrm{~b}$

To a stirred solution of N-protected amine $(R, R)-\mathbf{3 b}(47 \mathrm{mg}$, $0.12 \mathrm{mmol})$ in $\mathrm{MeOH}(4 \mathrm{~mL})$ was added $4 \mathrm{M} \mathrm{HCl}$ in dioxane $(180 \mu \mathrm{L}, 0.72 \mathrm{mmol})$, and the solution was stirred at r.t. for $2 \mathrm{~h}$. The reaction mixture was then concentrated under reduced pressure, diluted with EtOAc $(20 \mathrm{~mL})$, and washed with sat. aq $\mathrm{NaHCO}_{3}(20 \mathrm{~mL})$. The aqueous layer was extracted twice more with EtOAc $(2 \times 20 \mathrm{~mL})$. The combined organic layers were dried over $\mathrm{MgSO}_{4}$, filtered, and concentrated under reduced pressure Solvents were evaporated under vacuum. Purification by silica gel chromatography $\left(\mathrm{CH}_{2} \mathrm{Cl}_{2}-\mathrm{MeOH}=95: 5\right)$ allowed pure primary amine $\mathbf{4 b}(26 \mathrm{mg}, 75 \%)$.

$(R)$-1,2-Bis(4-nitrophenyl)ethylamine $(R)-(4 b)$

Yellow solid; mp 141-144 ${ }^{\circ} \mathrm{C} .{ }^{1} \mathrm{H}$ NMR $(200 \mathrm{MHz}$, $\left.\mathrm{CD}_{3} \mathrm{OD}\right): \delta=8.20(\mathrm{~d}, J=8.7 \mathrm{~Hz}, 2 \mathrm{H}), 8.11(\mathrm{~d}, J=8.7 \mathrm{~Hz}$, $2 \mathrm{H}), 7.56(\mathrm{~d}, J=8.7 \mathrm{~Hz}, 2 \mathrm{H}), 7.35(\mathrm{~d}, J=8.7 \mathrm{~Hz}, 2 \mathrm{H})$, $4.55-4.45(\mathrm{~m}, 1 \mathrm{H}), 3.27-3.14(\mathrm{~m}, 2 \mathrm{H}) .{ }^{13} \mathrm{C}$ NMR $(50 \mathrm{MHz}$, $\left.\mathrm{CD}_{3} \mathrm{OD}\right): \delta=149.0,148.4,146.2,146.2,131.7,129.3$, 124.8, 124.6, 57.7, 44.4. ESI-HRMS: $m / z[\mathrm{M}+\mathrm{Na}]^{+}$calcd for $\left[\mathrm{C}_{14} \mathrm{H}_{13} \mathrm{~N}_{3} \mathrm{O}_{4} \mathrm{Na}\right]^{+}: 310.07983$; found: 310.07965 . 